\title{
Rosenzweig between East and West: Restoration of India and China in The Star of Redemption
}

\author{
H. Ben Pazi \\ Bar Ilan University \\ Ramat Gan, 5290002, Israel
}

\begin{abstract}
This article will present Franz Rosenzweig's attitude toward the religions and cultures of East Asia, and his philosophical response to the trend of German Orientalism, and especially to Martin Buber's Ecstatic Confessions. Rosenzweig's references to India and China appeared systematically in the first book of the Star of Redemption, once for the analysis of metaphysics, second for the account of metalogic, and the third time as part of the discussion of meta-ethics. A close look at Rosenzweig's treatment of the cultures and religions of India and China in The Star of Redemption might lead a reader, even a careful one, to the conclusion that he did not seriously regard the dialogue between East and West as having any special significance. However, in this article I will ask to reevaluate the place of Indian and Chinese religions in the Star of Redemption, under Buber's influence. The cultural elements of Indian and Chinese mythologies contribute to the religious development of humanity — and take a significant part in the development of the religions of revelation and the course of redemption.

Keywords: Franz Rosenzweig, Martin Buber, Orientalism, India, China, Meditation, Creation - Revelation, Mystics, Ecstatic Confessions
\end{abstract}

\section{Article history:}

The article was submitted on 17.02.2020

The article was accepted on 14.05.2020

For citation: Ben Pazi H. Rosenzweig between East and West: Restoration of India and China in The Star of Redemption. RUDN Journal of Philosophy. 2020; 24 (3): 362-378. DOI: $10.22363 / 2313-2302-2020-24-3-362-378$

Buber's Ecstatic Confessions [1] played a critical role one of the most interesting intellectual developments in Germany at the turn of the last century: the emergence of German Orientalism. This was a literary, philosophical and linguistic cultural trend that demonstrated interest and admiration towards the cultures of the

(C) Ben Pazi H., 2020

This work is licensed under a Creative Commons Attribution 4.0 International License https://creativecommons.org/licenses/by/4.0/ 
East, and in particular, India and China ${ }^{1}$. Buber's goal in the book was to bring East and West closer together, as part of his broader conception of the tikkun of humankind through forging a link between East and West ${ }^{2}$.

A close look at Rosenzweig's treatment of the cultures and religions of India and China in The Star of Redemption might lead a reader, even a careful one, to the conclusion that he did not seriously regard the dialogue between East and West as having any special significance ${ }^{3}$. However I will endeavor to show that a more careful reading will lead to a different conclusion, and to a reevaluation of the place of Indian and Chinese religions in the Star of Redemption, under Buber's influence. Indian and Chinese culture, mythology, and literature will emerge as important foundations of Rosenzweig's work.

One of Buber's most interesting cultural theories was his perception of the influence of oriental teachings upon occidental culture. It is entirely plausible that Rosenzweig studied his ideas and integrated them into his own. For Buber, "None of the great religious teachings originated in the Occident. The Occident received and spiritually reworked what the Orient had to offer" [15. P. 68]. The West gives form to the great religious teachings of the East, and defines and shapes them. For Rosenzweig, the cultural elements from the East contribute to the religious development of humanity - its mythologies and mystical foundations play a part in the development of the three religions of revelation and redemption.

In an analysis of the first section of the Star of Redemption, I will show how Rosenzweig portrays both India and China, and gives expression, in pictures and parables, to what is ultimately ineffable. He undertakes the task of understanding the ecstatic movements of the Orient and the fruitful tension they create between mysticism based on "self-nullification" and mysticism based on "self-completion" (self-fulfillment) ${ }^{4}$. This reading of the first section reveals the particular use made by Rosenzweig of Buber's descriptions of the Orient and of Eastern mysticism ${ }^{5}$, and uncovers a reworking of the details of the structural discussion in the first section, and as a result, sheds new light on the later "Revelation" and "Redemption"

\footnotetext{
${ }^{1}$ On the German's Orientalism see [2; 3. P. 58-66; 4-8].

${ }^{2}$ Paul Mendes Flohr differentiated between the first and period on Buber's life and writings between his mystical period and his dialogical period. Buber himself described his change of thought, and explained it as a result of specific meeting with young person that came to visit him in Manheim; See the systematic analysis of Avraham Shapira to Buber's development, and the great significance of Buber's- "turn of heart"; According to this approach, Buber's early period, dedicated to the mystical attitude towards unity, must be distinguished from the later period during which Buber's foremost concern was the development of discourse and dialogue. See [9. P. 201-225; 10. P. $71-92 ; 11]$.

${ }^{3}$ A fair amount of research has been done on the place of East Asian civilizations in the Star of Redemption. See [12. P. 33 - 66; 13. P. 165-172; 14. P. 38 - 40, 54, 73-78].

${ }^{4}$ See [1. P. 10-13]. It is important to add that this argument is based on Rosenzweig's description of Eastern mysticism, rather than on his bibliographical references.

${ }^{5}$ As will be seen below, in the second and third parts of the Star of Redemption do not contain references to East Asia - India and China, as opposed to a very orderly pattern of references in the first part of the Star.
} 
sections as well $[16 ; 17 ; 18$. P. 265-271]. This reading will also shed new light on the central thesis of The Star of Redemption, the connection between Judaism and Christianity - between Judaism of the East and Christianity of the West.

A close reading Star of Redemption - still within the realm of the exoteric and not the esoteric - discloses a meaningful place for India and China in the first book. The first mention in the opening deals with the Whole (das Alle), where Rosenzweig touches upon the various possibilities for understanding the Whole: as pantheism, as a-cosmism, as divinity, and other phenomena ${ }^{6}$. There he refers to the Indian/Buddhist idea of heresy in considering pantheism and reverse pantheism [20].

Rosenzweig specifically refers to India and China in the first book three more times: as part of the discussions on metaphysics, metalogic, and meta-ethics, respectively [21]. This shows that his treatment of the East, with its mythological, linguistic, moral and social connotations, is indeed a relevant part of the complex structure of the Star. It should be stressed that it is not found in the Star's discussion of Revelation, in which Rosenzweig addresses all three monotheistic Western religions but only in the first part, "Creation."

\section{The View from Europe to the Orient}

It will be useful to briefly outline East-West relations from the European perspective, or more specifically, the attitude towards Indian and Chinese culture in European writing in modern times ${ }^{7}$. Europe's attitude toward India and China can be sharply divided into two periods: until the end of the 15th century, and from the beginning of the 16th century on. As far back as the Hellenistic period, one can find wonderful legends about the adventures of Alexander the Great in India. With Charlemagne, we find descriptions of India as a land of rich and abundant nature, the source of wealth and glory on earth ${ }^{8}$. These are accompanied by wonderful legends of magical beasts, of midgets and giants that are only found in India. During the Middle Ages, there was a legend about India's legendary ruler, Prester John (John the Priest), who had a very large Christian kingdom. The most widely-known example of this story of the legendary king of India in Hebrew literature is found in Yehuda Halevi's Kuzari ${ }^{9}$.

But all this changed when the genuine India was revealed by travelers to the Orient, and particularly by the arrival of Vasco da Gama in India in 1498. Information about the India as it really was became more common as the number of travelers increased, with many of them coming from Italy. Legend was replaced by reality, and the stories were supplanted by widespread curiosity and amazement. Parallel to this, about a century later, a similar curiosity developed regarding China,

\footnotetext{
${ }^{6}$ On the meaning of Das Alle in the Star of Redemption see [19].

${ }^{7}$ For a new perspective on the relations between East and West see [16; 17; 18. P. 265-271].

${ }^{8}$ On this historical literal trend see [22].

${ }^{9}$ I did not find a direct reverence in Rosenzweig's works to the legends of the King of India in the Kuzari.
} 
in the wake of the arrival of Portuguese explorers. Unlike India, China was regarded with great respect among Europeans, and even the prickly Voltaire describes it as a country that had put into practice Enlightenment ideas of tolerance and rationalism. Voltaire went so far as to argue that the Chinese religion is the true natural religion, liberated from superstition (unlike European Christianity) ${ }^{10}$.

The response of philosophers and historians to the Orient is far more significant. Beyond the popular curiosity of the masses, they began to reevaluate the historical connections and cultural relations between East and West. Figures such as Schlegel, Herder, Schopenhauer changed our picture of West-East relations in a profound way $[29-32 ; 33$. P. $35-50 ; 34 ; 35 ; 36$. P. 425-526; 37; 38]. They integrated into their work an interest in the Orient born of curiosity, and searched for a clearly ordered description of Indian mythology along the lines of those written for the Western mythology. They also initiated the new field of historical linguistics, aimed at identifying the genetic connection between Sanskrit and German $^{11}$. One of the guiding principles of the interest in India and China was the search for common sources of the Orient and the Occident.

Rosenzweig's approach to Eastern cultures was part of his philosophical analysis of human culture as a whole, and should be evaluated in light of the Orientalist trend of the early twentieth century. His relationship with Martin Buber played a role here as well, as the latter also wrote about the East and the West. Anecdotally, it should be noted that Buber's interest in this area originated with his wife, Paula Winkler, better known by her nom de plume, Georg Munk. Paula took part in a group known as "the New Community," which dealt with Eastern ideas and the languages of the Orient ${ }^{12}$ [43].

\section{Buber's Ecstatic Confessions}

Buber's attitude towards the East is the subject of many of his writings, but I will focus on his Ecstatic Confessions, and its important introduction. Published in 1909, the book played a central role in the bridge he hoped to build between East and West, and expressed his interest in the Orient better than any of his other books [1. P. 4]. It is a collection of various testimonies that describe mystical experiences from East and West alike, including those of Jalal ad-Din Rumi, Hare Krishna, Paul, and Meister Eckhart. Buber explains that he intends to gather a wide variety of material from individuals of different nations and historical periods who described their mystical and spiritual experiences in writing. For him, this collection was important for understanding the history of mysticism from both an aesthetic and

${ }^{10}$ The material on this subject goes beyond the limits of the present article, and much has written about these journeys from the political, economic and religious perspectives. And see [23-28].

${ }^{11}$ On the close relationship between Sanskrit and German see [39-42].

12 "Die neue Gemeinschaft" - The New Community — was an anarchist-communist commune run by the brothers Julius and Heinrich Hart, Eugen Diederichs, and Gustav Landauer between 1900 and 1904 in Berlin's Schlachtensee district. The members of this community were primarily politically-active life reformers, anarchists and artists. 
psychological perspective "because of the especially unusual poetic power" and for its authenticity [1. P. 13]. The confessions that he includes represent a broad range of mystical experiences, some similar and some different to each other, and provide him with a scholarly vantage point from which to analyze the ecstatic experience and its mystical significance.

The book includes an important preface, in which Buber characterizes and classifies the various mystical phenomena, a chapter which stands on its own as a significant contribution to the study of mysticism. It focuses on the ability of language to describe the ecstatic experience and tries to define its essence, and in that context, Buber clearly distinguishes between East and West. In his view, ecstatic experiences are rare in the West, and draw a great deal of attention and refection to themselves. In contrast, in the Orient they are common and widespread, and less is written about them. For the purpose of my discussion, two points should be highlighted: first, the connection he between East and West and the similarities between the mystical experience in the Orient and those familiar in the West. Second, the crucial distinction he draws between two types of mystical experiences: being emptied out and being completed.

\section{China and India in the Star of Redemption}

Rosenzweig regards the cultures of India and China as primitive cultures, part of the ancient history of humanity. But at the same time, he clearly states that these cultures continue to play a significant role in modern history. In a picturesque description he writes: «The godheads of China and India are immense edifices built from the blocks of ancestral times; like monoliths, they still tower up to this day in the cults of the 'primitives'» [44. P. 43 - 44]. For Rosenzweig, the East — India and China - retains its importance in world culture.

I contend that in his views of the Orient Rosenzweig follows Buber's lead. The best example of this is his portrayal of a mystical practice of the East, the mantra of "Om" [44. P. 44]. This incantation can express affirmation, and repeating it opens the secrets of existence: "the undivided essence," that tolerates all multiplicity, the thingness of all things. The mantra "Om" can identify with "yes," with affirmation, but also reveals what is beyond it, the "infinite multiplicity" [44. P. 44].

Obviously, the meaning of Om is rich and complicated, and it is relevant to the idea of the Whole (das Alle) of Rosenzweig. A well-known description of this idea is found in the Upanishades: "The word which all the Vedas proclaim / That which is expressed in every Tapas / That for which they live the life of a Brahmacharin / Understand that word in its essence: Om! that is the word. / Yes, this syllable is Brahman / This syllable is the highest / He who knows that syllable / Whatever he desires, is his" [45; 46. P. $284-286$; 47. P. 244-297; 48]. Due to Rosenzweig's limited knowledge of the East, he did not know that instead he could have used the meaning of Om in the Vedas for his purposes. The "Om" mantra in Kathak Sanhita 
is also the voice of the Creator and the voice of the one who brings redemption ${ }^{13}$. God's loneliness created speech whose sound is heard as "Om," and it is that which put an end to the loneliness [47. P. 244-297].

The triangular structure of the Star of Redemption allows us to search for the references to China and India with relative ease. The real dialogue towards redemption sought by Rosenzweig inheres in the relationship between Judaism and Christianity as religions. To establish this dialogue, he began with the wide range of religious ideas found in Greek, Chinese, and Indian mythology, so as to give universal meaning this quest. The second stop on his journey is revelation and an evaluation of the religions of revelation: Islam, Christianity and Judaism.

Given this framework, we can understand the role of oriental religions in the first book of the Star. It has been thought that his interest in the East is so tangential that virtually no one considered studying his attitude to the Orient in these sources. Nevertheless, Rosenzweig describes the central role of Oriental religions as follows: "The godheads of China and India are immense edifices built from the blocks of ancestral times" [44. P. 43]. This statement should lead us to rethink the place of "the Orient" in Rosenzweig's writings. In light of the intellectual crosscurrents of turn-of-the-century, we have in the first part of the Star the search for the source of spirituality in the cultures of China and India.

The search turns out to be particularly successful and fruitful, as an overview of the three-part division demonstrates. The first book of the Star is divided into three sections: meta-physics, which is where we find the discussion of God; metalogic, where we find the discussion of the world; and meta-ethics, where we find the discussion of the human being. In each of the three parts of the first book, Rosenzweig discusses Eastern religions: as part of the discussion of logic, of metaphysics, and ethics, respectively. In the context of our inquiry here, one can understand how Rosenzweig employs India and China to redefine his thinking about God. He reexamines the meaning of Being and Nothingness, that is, the concepts of "Nothingness," "Being," and of "Becoming"-which find expression in a number of forms: from Nothingness to Being, from Being to Nothingness, from Being to Nothingness to Being [44. P. 23-29]. Moving between concepts, Rosenzweig attributes meanings to the concept of presence - the presence that has no name and the presence that has a name. This dynamic between Nothingness and Being has significance from metaphysical, logical, and meta-logical perspectives, as well as from an ethical or meta-ethical perspective.

It must be pointed out that a careful reading reveals the dialectical use Rosenzweig makes of Asian cultures - while distinguishing between India and China - and between Nothingness and Being. He surprises his readers with the interest he takes in the cultures of the Orient and Asian cultures in the new pattern of his thought.

\footnotetext{
${ }^{13}$ On the meaning of the Om and the question of Kathak Sanhita, see the classical work of Friedrich Max Müller [52. P. 13; 53. P. 9-16].
} 
In broader terms, before the word was created, before the philosophical and existential parameters of metaphysics, logic, and ethics were delineated, and certainly before the West thought in terms of the "self," the "subject," or "revelation," the first ultimate questions were those of existence and nothingness, and they were already part and parcel of the practical wisdom of the East. This wisdom is still integral to the religions and cultures of the East Asia - mainly India and China.

\section{Metaphysics or God}

"About God we know nothing, but this not-knowing is a not-knowing about God. As such, it is the beginning of our knowledge about him" [44. P. 31]. That is the way Rosenzweig opens the section on metaphysics in the first book of the Star. His discussion appears under the heading of God and Being. At the outset, Rosenzweig explains his analysis of negative theology as it appeared not only in the Middle Ages but also in Kant, and sets off to find the meaning of negation and affirmation. The God that is a product of this linguistic analysis leads us to describe Him in these terms: "He is dependent on nothing besides himself and seems not to need anything besides himself" [44. P. 41].

In discussing the meaning of God's vitality, the issue of the vitality of the gods of mythology comes up. They are immortal, but not because death does not reach them, but rather because death is beneath them. Nature belongs to the gods. When a god joins a constellation or the like, he does not become the god of the constellation, as we would think by retrospectively projecting our concept of nature: it is rather the constellation that becomes god or at least part of god [44. P. 42].

In order to examine the manner in which the idea of God develops from within the world of myth, we have to go back and take a close look at the essence of myth and its function in the development of religious consciousness: "The law of this life is the harmony of arbitrariness and fate, an inner harmony that does not resound beyond itself and always returns within itself" [44. P. 42].

For this is the essence of myth: a life that knows nothing above or beneath itself; a life that knows neither of things ruled over or of ruling gods, a life purely in itself, whether the bearers of this life are gods, people or things [44. P. 42]. Taking it further, the law of mythic life is an internal law, appropriate to itself and paying no heed to what is beyond itself, caught in constant return to "arbitrariness and fate" [44. P. 42]. The transition from Creation to Revelation is a transition from the mythic to the religious. The mythic is a necessary developmental stage in any case, so it should not be regarded as an inferior form when compared to the spiritual religions of the Far East. The conceptions of divinity of India and China, he says, continue to be stable in our own world, sort of "like monoliths, they still tower up to this day" [44. P. 43].

In his description of mythology, Rosenzweig indicates that he recognizes its significance as well as the significance of the "religions of the spirit" of the East. It is at this juncture that he tries to understand why revelation is a product of Western 
religious thought and not Eastern. Note that in the excerpt below he considers the importance of the continued existence of the spiritual religions of the East in our world as well:

Until its decline in the religions of the Near East and of Europe, the mythical prevailed everywhere as a stage of evolution; it does not mean an inferior form, but, rather, a higher form with regard to the Eastern 'religions of the spirit'. It is no coincidence that the Revelation, when it went out into the world, did not take the path of the East but that of the West. The living 'gods of Greece' were worthier opponents for the living God that were the phantoms of the Asiatic East. The godheads of China and India are immense edifices built from the blocks of ancestral times; like monoliths, they still tower up to this day in the cults of the 'primitives'. China's Heaven is the concept raised to the world-embracing, of divine power which, without pouring forth over the divine essence and thus being configured into the divine vitality, arranged the entire universe into enormous ball of its ruling arbitrariness; is not as another thing, but as a thing that it contains in itself. A thing that 'inhabits' it; nowhere does the graphic sense of the idea of immanence become as clear as in this Chinese deification of the vault of the heavens, outside of which - is nothing [44. P. 43-44].

Rosenzweig is not only attracted to the anthropological and mythological aspects of the religions of the spirit, but to the way they collectively address the most important question of all, that of nothingness and existence, and more precisely, the question of nothingness. The religions of the spirit engender the primal and final experience, in the transition between "all-embracing power" and the purest form of all, the silence of existence. Rosenzweig fascinates us by using Hermann Cohen's terminology in his analysis of the infinitesimal in order to understand the striving to the edge of nothingness:

And just as China's God is exhausted in going from the nothing to the all-embracing power, so, too, for India's God on the road between the nothing and the pure, all-penetrating silence of the essence, of the divine nature. The sound of divine freedom never penetrated into the silent circle of the Brahmin; so it itself remains dead. Although it may fill all life of the gods of myth, these 'deities' - the word of all those who take flight before the countenance of the living God into the dense fogs of abstraction - are the regressions into that which is rudimentary. We learn the extent to which these are regressions by a glance at the regressions that those elementary constructions mentioned above undergo in their turn: for once begun, this momentum of regression does not cease before it has reached almost its outer limit - the nothing [44. P. 43-44].

Rosenzweig's description teaches us about the two most basic movements of myth: from Nothingness to Being, and from Being to Nothingness. From Nothingness to Being is the movement of Chinese myth, while the movement from Being to Nothingness is that of Indian myth. Thus, one should not relate to the religions of India and China as a primitive form of religion, but as the highest form of spiritual religion. 
What makes the Tao useful, says Rosenzweig is that its action is accomplished without activity. He says that it is like the axle of a wheel, windows in a wall, or in a more effective image, like the space inside a vessel. After all, what makes the vessel into a vessel is the nothingness inside it [49].

Rosenzweig focuses on Chinese myth, describing it as the pinnacle of the idea of divine immanence, "the Divinity of the Sky" - this is the divinity as omnipotence that encompasses everything. By way of contrast, the second movement is that of Indian myth, which is the most full and profound movement of Nothingness itself ${ }^{14}$.

The cultures of China and India do not come to us from the distant past, but are instead existent and stable even today. Of course, the question is what they place before us within the present, within their presence. It seems to me that the complex answer is intimately related to the nature of calling something by name in the Star. The uniqueness of India and China for Rosenzweig is not their being called by name or a dismissive attitude toward calling by name, not mere "smoke and dust," but in the dialectic necessary for understanding calling something by name: between Being and Nothingness, and between becoming and becoming-null. Thus, for Rosenzweig the concept of revelation as calling-by-name is established with the help of the complex dialectic between Nothingness and Being, between the all-encompassing ability and the sacred silence that penetrates everything.

\section{Meta-logic}

We will now proceed on to the second part of the first book, to meta-logic, on the path to recognition of the individual. At the center of the treatment of China and India, the question arises about the distinction between thinking about the world and experience within the world. In this regard India has a formative role. Rosenzweig engages in an examination of the process that nullifies Being and sees beyond it: "What is it we know of the world? It seems to surround us. We live in it, but it is also inside us. It gets into us, but with every breath we breathe and with every move of our hands, it flows back out of us" [44. P. 49].

Rosenzweig examines the various possible ways to perceive the world - that which moves in tension between the particular and general, between idealism and phenomena, between the individual human being and society and introduces Eastern thought into the discussion. For Rosenzweig, the Asiatic thinkers did not succeed in reaching the end-stage of philosophical development, as did Greek thought; they halted at the ante-room of yes and no, of affirmation and negation. Jewish thought, on the other hand, tried to find the general principles behind the details of the world.

Another example of the way that Rosenzweig deals with the Indian cultures, relates to the Hymns. Rosenzweig writes that the role of hymns in Indian ritual is to renounce the unique face of the specific god in order to take on the appearance

\footnotetext{
${ }^{14}$ In order to understand the meaning of the comparison that Rosenzweig makes with the East, by way of Buber's approach, see [1. P. 11-12].
} 
of "the unique supernal god." The role of the myths, theoretically, is to create a system of categories - water, wind, breath, fire, and others - that provide an explanation for reality, or the essence of reality. Individual phenomena in the world are only an illusion simultaneously masking and disclosing the essence behind them. This line of thinking culminates in the way of Buddhism, which he describes in these terms: "Again the point is reached just before the border of the nothing and yet far behind the infinite universality of knowledge that denies the nothing thus affirms itself infinitely" [44. P. 67-68].

And in a complete mirror image, China offers a multiplicity of shades and an infinite number of details as the basis of reality. Confucius, says Rosenzweig, understands the world in the form of "the spirits," not in the form of the one Spirit:

"The spirits become entirely individual individuals, themselves having a name and bound most particularly to the name of the worshipper: the spirits of his ancestors" [44. P. 67].

The unity of concepts above their multiplicity, Rosenzweig argues, is foreign to China. The community to which the individual belongs is the chain of his ancestors, which grants particular significance to that individual and confirms his significance. For Lao-Tse these ideas are not sufficient, so he sets out in search for the one root from which all is formed: "Lao-tse teaches the overcoming of the concrete plenitude of becoming by means of the silent entry, without any activity, into the original, nameless abyss of becoming visible and named" [44. P. 68].

The long piece cited below can be read in a number of ways - both positively and negatively. However, I choose to read it from an affirmative perspective, because it enables Rosenzweig to ask the question of the individual in a way he had not done previously, before he cited the influence of the East. This reading is a demanding one, because in it we see the nullification of the self in the Eastern tradition.

Once again, India and China each developed an aspect of the elementary being, prior to structure, by energetically limiting itself to the most elevated being. For long before, with its obstinate spirit, Indian thinking covered the world's plenitude with its veil of the Maya, long before it asserted only the 'Self' in all things and dissolved this Self anew in the oneness of the Brahmin; this thinking, already since its first beginnings, deviates from the determination of the particular and seeks a universal that would be behind it. It has been noted that as far as these world hymns that accompanied the sacrifice, the singular God assumes the traits of the supreme and unique God, by forfeiting his own face for the poet. Hymns that begin in the greatest individuality die away in colorless universality. Amid the troop of the oldest gods tied to nature, at an early stage divine figures creep in of a purely allegorical origin, as later happened in Rome. But in India, this is only the symptom of dissolution in the thinking of the world in general. The question of the origin of the world is solved by a legion of juxtaposed, learned pseudo-myths, each of which, under cover of a legend of origin, actually developed a system of categories. Water, wind, breath, fire and all the rest - these are not elements of a reality but early on 
they borrow the countenance of prescientific fundamental concepts to explain the world, a world which is certainly not receives, not experienced, but first of all 'explained'. The priest does not offer up real things but the essence of things; it is only because they are essence that they can be put on the same footing as the essence that they can thus directly affect it. So, everything is ready for the world to become a system of concepts; it is certainly still a system of the world and reality, but without any autonomous right conceded to the particular, which can only be reckoned as 'illusion'. And in its turn, the doctrine of the Buddha reaches back beyond this objective world of concepts and designates, as essence of these essences, the concepts of knowledge. In a series of concepts of knowledge there dissolved that which had still remained solid in this world that had vanished in the concept; and in the suppression of the knowing and desiring I, the whole world, generated by this knowledge and desire finally disappeared along with its gods and its essence into the nothing. Into nothing? No, here also to avoid the term 'nothing' which still always contains a musty taste of positivity, into a realm beyond knowledge and not-knowledge. Again the point is reached just before the border of the nothing and yet far behind the infinite universality of knowledge that denies the nothing thus affirms itself infinitely [44. P. 66-67].

From a logical perspective Rosenzweig considers this is an exceptional accomplishment of the East, whereas he does not consider the boundaries of knowledge in the same way. He does not confirm the infinite as the great idea, but rather the ability to reach-even incompletely — the "infinite" itself.

\section{Meta-ethics}

In the third section of the first book, Rosenzweig takes up the discussion of humankind. He begins with the fundamentals: do we really know anything about man? Alternatively, do we know nothing about man as well as knowing nothing about everything else? The question of man, of the self, as Buber will later formulate it, must be answered if we are to establish a basis for ethics. One way to answer it to use Hegel's frame of reference, that of the conscious that knows itself. The question that bothered Rosenzweig, beyond establishing the subject, was the ability of the subject to say "I." This is, perhaps, Kant's greatest achievement, in that he succeeded in making the self-evident into the most remarkable thing of all the "I" into something whose central sense is something about which there are questions.

Rosenzweig describes the birth of selfhood with death, the type of which makes possible the birth of selfhood. Here, India and China assist Rosenzweig's thinking for they are cultures that did not succeed in traversing the whole distance, so to speak, and thus they teach what is not self-evident. India has frozen each person into the situation in which he belongs, into the caste in which he was born, into the role that was thrust upon him. Sanctity is nothing heroic, but on the contrary: "It is the universal and same inner necessity of life" [44. P. 83]. Rosenzweig's explanation is logically precise, even if it is imprecise from the 
perspective of vantage point of religion and history. The only two ways in which a person can escape from his selfhood - that is, from being a tragic hero-are India's and China's: "Historically, on the soil of India and China, the flowers of the tragic have not grown at all" [44. P. 84].

The tragic hero, the hero of the revolt, from whom the power of an individual's independence is drawn, is marked with the seal of Samson: "Let me die along with the Philistines."

Rosenzweig's goal is to confer meaning to the individual, to the person known by the name given to him. It is not the creation of humankind that interests him, but God's calling by name the person He had created: "Adam"—not adam as a common noun but "Adam" as a proper noun, a person's name. He was not concerned with the knowledge of divinity or reality, what is known as Being or as Nothingness, but the divinity that people attain by being called by a name.

The particular name is not vanity and emptiness, says Rosenzweig, in opposition to Mephistopheles in Goethe's Faust, but under this layer — the name - rests another layer of revealing of Being and Nothingness ${ }^{15}$. Revealing Being by connecting to all of reality - is the ecstasy of being filled, and revealing Nothingness through exiting from reality - is the ecstasy of being emptied. These two movements, important for Rosenzweig from a logical point of view, are important from a theological—metaphysical point of view as well, and in the final analysis, from an ethical, dialogical point of view, because dialogue is established between the one who is called by name and the one who utters it.

We now arrive at a point that our reading of Rosenzweig requires that it be read again carefully. From a clear and direct standpoint, he argues that the boundary reached by Indian and Chinese culture is the individual. The renunciation of the "self" follows on from the renunciation of the tragic figure, the one who instigates the movement of the individual. While it is difficult to locate the source he relies upon for his contention, for Rosenzweig this is the inner meaning of the Buddha that is, the pinnacle to which the individual can aspire upon receiving enlightenment, the nullification of individuality.

The tragic hero of antiquity is nothing other than the metaethical Self. So the tragic came alive only where antiquity traversed the entire road that produces this image of man. India and China, which stopped on the way before reaching the goal, achieved the tragic neither in the dramatic work of art nor in the prefiguring if the folk-tale, India never arrived at the identity of the Self that displays its defiance in all the characters; the Indian man stayed stuck in the character; there is no world more rigid from the point of view of character than that on Indian poetry; there is no human ideal which stays as much a prisoner of all articulations of the natural character as does the Indian ideal; it is certainly not only to the sexes, or the castes, but even to the ages of life that a particular law of life applies; the highest duty is that man obey this law of his particularly; not everyone has the right or even perhaps the duty to become a

${ }^{15}$ Regarding Rosenzweig's references to Mephistopheles see [50. P. 230-249]. 
saint; quite on the contrary, it is forbidden to the man who has not yet established a family; even saintliness is here one particularity among others, whereas the heroic is the universal and same inner necessity of life for everyone [44. P. 82-83].

While Rosenzweig's overall proficiency with Buddhism if far from complete, one must be impressed with the serious way in which he comprehends Buddhism's doctrines of the self and its nullification, including the conscious renunciation of the name Siddhartha in favor of spiritual illumination itself. Buddha invites everyone to become Buddha, with its nullification of the self, its asceticism which is not the asceticism of the "I" but the ability to transcend oneself, into existence itself.

Once again, the asceticism that culminates in the Buddha is the first to go back behind this particularity of character. The perfect one is detached from everything, except from his own perfection. All conditionings of the character have fallen away, neither age, nor caste, not the sex counts here; the one unconditional character remains, liberated from all condition, precisely that of the liberated one. Even that is still character; the liberated one is separated from the not-liberated one; but the separation is quite different from what usually separated one character from another; it is behind these conditional separations as the one conditional separation. So, the liberated man is character in the moment of his emergence from - or more accurately of his entry into the nothing, between the liberated one and the nothing there is really nothing more than the complement of individuality which combines with the character, owing to the participation in the world of all that lives as long as it lives. Death, which allows this piece of individuality to stream back into the world, removes this last wall of separation which separates the liberated man from the nothing, and it robs him even of the character of liberation [44. P. 82-83].

\section{Conclusion}

This article has addressed Rosenzweig's attitude toward the cultures of the East, as it appears in the Star. It is set against the yearning for the East that became an integral part of modern German culture, particularly at the end of the 19th and the dawn of the $20^{\text {th }}$ century. As noted, I regard Rosenzweig's interest in the East as being directly influenced by Buber's writings on the subject at the time. A close reading of the Star shows that Rosenzweig seriously implemented Buber's counsel to read the religious literature of the East, including his introductions and descriptions in the Ecstatic Confessions, his book on the Tao dedicated to Lao Tse's thought, and a number of other articles and speeches on the East.

A painstaking and systematic reading of the Star, especially the first part, brings the discussion of the Orient to light and we find that for Rosenzweig, the cultures of India and China still stand as foundational pillars of the world, even at present. India and China, are discussed in each of sections of the first part of the 
Star and they play a decisive role in its overall structure and the interrelationship of its various parts.

I would like to return to the Indian meditation "Om" as an echo of creation and of self-nullification. This is the way I understand the meaning of myths in the section on metaphysics, of Being and Nothingness in the section on meta-logic, and the meaning of the tragic in the section on meta-ethics. The complex movements between Being and Nothingness, and between Nothingness and Being, between self-fulfillment and self-emptying, which can be read just as modes of metaphysical philosophical thinking, are, in the religions of the East, spiritual movements that provide, at the end of the process, a place for the individual, the particular, to appear and be revealed. This brings to an understanding of the importance of Eastern religions, not only as footnote in the history of humankind but as a profound spiritual movement, laying the foundations for revelation in the West.

\section{References}

[1] Buber M. Ecstatic Confessions. The Heart of Mysticism. Edited by Paul Mendes-Flohr. Translated by Esther Cameron. New York: Harper and Row; 1985.

[2] Kontje T. German Orientalisms. Ann Arbor. MI: University of Michigan Press; 2004.

[3] Marchand S. German Orientalism in the Age of Empire: Religion, Race, and Scholarship; 2009.

[4] Cowan R. The Indo-German Identification: Reconciling South Asian Origins and European Destinies. 1765-1885. New York; 2010.

[5] Rothermund D. The German Intellectual Quest for India. New Delhi; 1986.

[6] App U. The Birth of Orientalism. Philadelphia: University of Pennsylvania Press; 2010.

[7] Kabbani R. Imperial Fictions: Europe's Myths of Orient. London: Pandora Press; 1994.

[8] John MK. Orientalism: History, theory and the arts. Manchester: Manchester University Press; 1995.

[9] Flohr PM. The road to "I and Thou": an inquiry into Buber's transition from mysticism to dialogue. Texts and Responses. Studies Presented to Nahum N. Glatzer on the Occasion of His Seventieth Birthday. Michael A. Fishbane and Paul R. Flohr (eds.), Leiden: E.J. Brill; 1975.

[10] Flohr PM. Martin Buber between Nationalism and Mysticism. Iyyun: The Jerusalem Philosophical Quarterly 29; 1980.

[11] Shapira A. Hope for our Time: Key Trends in the Thought of Martin Buber. Trans.: Jeffrey M. Green. Albany: State University of New York Press; 1999.

[12] Wolfgang B. In China: über das Motiv der Gewalt bei Walter Benjamin und Franz Rosenzweig. Rosenzweig Jahrbuch 6; 2011.

[13] Pollock B. Franz Rosenzweig and the Systematic Task of Philosophy. Cambridge University Press; 2009.

[14] Samuelson NM. A User's Guide to Franz Rosenzweig's Star of Redemption. Routledge; 2010.

[15] Buber M. On Judaism: An Introduction to the Essence of Judaism by One of the Most Important Religious Thinkers of the Twentieth Century. Edited by Nahum N. Glatzer. New York: Schocken Books; 1967.

[16] Said E. Orientalism. New York: Vintage Books; 1979.

[17] Vermeiren D. Orientalism in the Middle Ages: The representation of Muhammad by Jacob van Maerlant's 'Spiegel Historiael'. 
[18] Pick LK. Edward Said, Orientalism and the Middle Ages. Medieval Encounters. 1999; (5).

[19] Pollock B. Knowing the all: Franz Rosenzweig's system of philosophy. Dissertation. Hebrew University of Jerusalem; 2006.

[20] Freund ER. Franz Rosenzweig's Philosophy of Existence: An Analysis of "The Star of Redemption. The Hague: Martinus Nijhoff; 1979.

[21] Mosès S. System and revelation: the philosophy of Franz Rosenzweig. Foreword: Emmanuel Lévinas. Trans.: Catherine Tihanyi. Detroit: Wayne State University Press; 1992.

[22] Inden R. Imagining India. Indiana University Press; 2000.

[23] Jeyaraj D. Bartholomäus Ziegenbalgs Genealogie der malabarischen Götter. Edition der Originalfassung von 1713 mit Einleitung. Analyse und Glossar von Daniel Jeyaraj. Halle: Neue Hallesche Berichte; 2003.

[24] Lehmann A. Alte Briefe aus Indien, Unveröffentlichte Briefe von Bartholomäus Ziegenbalg (1706-1719). Berlin; 1957.

[25] Settgast AC. Der Mann in Tranquebar: Ein Porträt des Bartholomäus Ziegenbalg. Brendow Verlag. Moers; 1987.

[26] Scrafton L. Reflections on the Government, \&c. of Indostan: With a Short Sketch of the History of Bengal, from the Year 1739 to 1756; and an Account of the English Affairs to 1758. HardPress; 2018.

[27] Scrafton L. A History of Bengal before and after the Plassey. 1739-1758. Calcutta: Editions Indian: [Sole distributors, Firma K.L. Mukhopadhyay]; 1975.

[28] Naji O. The Progress of an Image: The East in English Literature. New York: Peter Lang Publishers; 1996.

[29] Hegel GWF. The Philosophy of the Oriental World. American Classical College Press; 1992.

[30] Tibebu T. Hegel and the Third World: The Making of Eurocentrism in World History. Syracuse, NY: Syracuse University Press; 2011.

[31] Viyagappa I. G.W.F. Hegel's Concept of Indian Philosophy; 1980.

[32] Rothermund D. The German Intellectual Quest for India; 1986.

[33] Bernasconi R. With what must the history of philosophy begin? Hegel's role in the debate on the place of India within the history of philosophy. Hegel's History of Philosophy: New Interpretations. David A. Duquette (ed.); 2003.

[34] Herling BL. The German Gìtā: Hermeneutics and Discipline in the German Reception of Indian Thought. 1778-1831. 2006.

[35] Cowan R. The Indo-German Identification: Reconciling South Asian Origins and European Destinies. 1765-1885. 2010.

[36] Schlegel, F. On the Language and Wisdom of the Indians. The Aesthetic and Miscellaneous Works of Frederick von Schlegel. Ed. and trans.: E.J. Millington, London; 1849.

[37] Schopenhauer and Indian Philosophy: A Dialogue between India and Germany. Arati Barua (ed.). New Delhi: Northern Book Center; 2008.

[38] Cross S. Schopenhauer's Encounter with Indian Thought: Representation and Will and Their Indian Parallels. Society for Asian and Comparative Philosophy: University of Hawai'i Press; 2013.

[39] Bradke P. Über Methode und Ergebnisse der arischen (indogermanischen) Alterthumswissenshaft; 1890.

[40] Walter P. Die Gliederung des indogermanischen Sprachgebiets. Heidelberg: Carl Winter Universitätsverlag; 1954. 
[41] Colin R. Archaeology \& Language. The Puzzle of the Indo-European Origins. London: Jonathan Cape; 1987

[42] Brugmann K. Grundriss der Vergleichenden Grammatik der indogermanischen Sprachen. Strassburg: Karl J. Trübner; 1886.

[43] Michael Löwy. Redemption \& Utopia: Jewish Libertarian Thought in Central Europe, a Study in Elective Affinity. Trans.: Hope Heaney. Stanford, CA: Stanford University Press; 1992.

[44] Rosenzweig F. The star of Redemption. Translated by Barbara E. Galli. Foreword by Michael Oppenheim. Introduction by Elliot R. Wolfson. The University of Wiscontin Press; 2005.

[45] Upanishad K. 1.2.15-1.2.16.

[46] Deussen P. Sixty Upanishads of the Veda I. Motilal Banarsidass. P. 284-286.

[47] Gonda J. The Indian Mantra. Oriens. 1963; (16): 244-297.

[48] Studholme A. The Origins of Om Manipadme Hum: A Study of the Karandavyuha Sutra. State University of New York Press; 2012.

[49] Lao Tzu. A Book About the Way and the Power of the Way. Chapter XI; 1998.

[50] Ben-Pazi H. The Path that leads to the One God, must be walked in part without God. The Germanic Review: Literature, Culture, Theory. 2018; 93 (3): 230-249.

[51] Fortson BW. Indo-European Language and Culture: An Introduction. Malden Massachusetts: Blackwell; 2004.

[52] Müller FM. The Sacred Books of the East. Clarendon Press; 1891.

[53] Knapp S. The Heart of Hinduism: The Eastern Path to Freedom, Empowerment and Illumination; 2005.

\title{
About the author:
}

Ben Pazi Hanoch - Professor, Department of Jewish Philosophy, Chair Bar Ilan University, Ramat Gan, Israel (e-mail: benpazh@mail.biu.ac.il).

\section{Розенцвейг между Востоком и Западом: Восстановление Индии и Китая в «Звезде избавления»}

\author{
Х. Бен Пази \\ Университет Бар-Илан \\ Ramat Gan, 5290002, Israel
}

В этой статье будет представлено отношение Франца Розенцвейга к религиям и культурам Восточной Азии, а также его философский ответ на тенденцию немецкого ориентализма, и особенно на работу Мартина Бубера «Экстатические конфессии». Ссылки Розенцвейга на Индию и Китай систематически появлялись в первой книге «Звезды избавления», один раз для анализа метафизики, второй - для описания металогики и третий раз как часть обсуждения метаэтики. Внимательный взгляд на отношение Розенцвейга к культурам и религиям Индии и Китая в «Звезде избавления» может привести читателя, даже осторожного, к выводу, что он не всерьез рассматривает диалог между Востоком и Западом как имеющий какое-либо особое значение. Однако в этой статье я попытаюсь переоценить место индийской и китайской религий в «Звезде избавления» под влиянием Бубера. Культурные элементы индийской и китайской мифологии способствуют религиозному развитию человечества — и принимают существенное участие в развитии религий откровения и в направлении избавления. 
Ключевые слова: Франц Розенцвейг, Мартин Бубер, ориентализм, Индия, Китай, медитация, Творение-Откровение, мистики, экстатические конфессии

\section{История статьи:}

Статья поступила 17.02.2020

Статья принята к публикации 14.05.2020

Для цитирования: Ben Pazi H. Rosenzweig between East and West: Restoration of India and China in The Star of Redemption // Вестник Российского университета дружбы народов. Серия: Философия. 2020. T. 24. No 3. C. 362-378. DOI: $10.22363 / 2313-2302-2020-24-3-$ $362-378$

\section{Сведения об авторе:}

Бен Пази Ханох - профессор кафедры еврейской философии, Университет им. Бар-Илана, Рамат-Ган, Израиль (e-mail: benpazh@mail.biu.ac.il). 